Article

\title{
Hierarchical Self-Assembly of Amino Acid Derivatives into Enzyme-Responsive Luminescent Gel
}

\author{
Yibao Li *, Yu Peng, Wei Liu, Yulan Fan, Yongquan Wu, Xun Li * and Xiaolin Fan
}

Key Laboratory of Organo-Pharmaceutical Chemistry, Gannan Normal University, Ganzhou 341000, China; m18070470780@163.com (Y.P.); weiliufangsheng@163.com (W.L.); fanyl@gnnu.cn (Y.F.); wyq@gnnu.edu.cn (Y.W.); fanx12013@gnnu.cn (X.F.)

* Correspondence: liyb@gnnu.cn (Y.L.); gnsylx@163.com (X.L.); Tel.: +86-797-839-3536 (Y.L.)

Academic Editor: Manel Del Valle

Received: 15 November 2016; Accepted: 25 January 2017; Published: 7 February 2017

\begin{abstract}
In this study, a novel three-component hydrogel has been designed and fabricated via hierarchical self-assembly by amino acid derivative $\left(N, N^{\prime}\right.$-diphenylalanine-3,4,9,10-tetracarboxylic diimide (NPPD)), riboflavin (RF) and $\alpha$-cyclodextrin ( $\alpha-\mathrm{CD})$. These molecules were aggregated to form some fibrous structures based on hydrogen bond and $\pi-\pi$ stacking. The results show that the hydrogel has a specific response to $\alpha$-amylase and the fluorescence disappears once hydrolyzed. Therefore, this multi-component hydrogel has potential application in the field of drug delivery.
\end{abstract}

Keywords: hydrogel; amylase-response; hydrogen bond; drug delivery

\section{Introduction}

The stimuli-responsive hydrogels, responsive to subtle changes in ambient systems, are of great interest to researchers; their use ranges from physical triggers to chemical triggers due to their wide application in drug delivery, sensors, and molecular recognition [1]. Another potential application is as the $\mathrm{pH}$-responsive luminescent gel display in nano $\mathrm{pH}$ sensors [2]. The stimuli-responsive methods include temperature, pressure, $\mathrm{pH}$, concentration, enzyme, light, etc. [3-6]. Among the above different stimuli-responsive methods, enzymes have great advantages. The enzyme is a substrate-specific, highly efficient catalytic under mild conditions and is associated with disease [7-11]. The biology has a vast enzymatic stimuli-responsive material because all processes are ultimately controlled by enzymes in living organisms [9]. Thus, it is necessary to design and fabricate new stimuli-responsive materials. Furthermore, these self-assembled nanostructures could be designed with novel peptide motifs [12-14].

Recently, the enzyme-responsive systems fabricated by non-covalent interactions have attracted more and more attention [15-23]. As one of the non-covalent interactions, $\pi-\pi$ stacking is vital to accelerate the alliance of supramolecular compounds to provide self-assembled structures with high stability [24]. Up to now, a lot of research for enzyme-responsive systems has been reported [25-29]. For instance, Zhang and coworkers have constructed several polymers by the electrostatic interaction between components responsive to phosphatase or acetylcholine [30-33]. In general, most enzyme-responsive materials consist of two components: (i) an enzyme sensitive component, which is a substrate or substrate mimic based on a biomolecule (such as a peptide, a lipid or a polynucleotide); (ii) a component that directs and controls changes in non-covalent interactions [8]. Compared with covalently modifying the building blocks, utilizing the non-covalent bond to build the enzyme-response system has some advantages. For example, it is easier to modify or regulate the function of the system and it reduces the difficulty of synthesis and purification. 
In this work, we have attempted to fabricate an amylase response gel using a non-covalent bond between amino acid derivatives and guest molecules. As is shown in Figure 1, the amino acid derivative (NPPD) was synthesized by 3,4,9,10-perylenetetracarboxylic dianhydride and phenylalanine via amino bond. The phenylalanine with an aromatic ring can affect the morphology of the assemblies and reduce the minimal association concentrations [34-38]. In addition, the perylene is a classic organic chromophore with strong $\pi-\pi$ stacking. A compound with a chromophore could form hydrogel, which may have advantageous photonic and electronic characteristics [39]. Riboflavin with the conjugated aromatic moieties, named flavin nucleotides, behaves as a photoreceptor in the phototropism of plants, plays a significant role in various biochemical processes in plants and also acts as a perfect component in hydrogel systems [40]. As a guest molecule, the $\alpha$-cyclodextrin $(\alpha-C D)$ plays a key role in the specific response of the $\alpha$-amylase. Moreover, the $\alpha$-CD molecules can form four hydrogen bonds, because there is a glucose unit in the position of the distortion. The three compounds could form hydrogel under ultrasound at low temperature $\left(\sim 15^{\circ} \mathrm{C}\right)$. When the $\alpha$-amylase was added at $37^{\circ} \mathrm{C}$, the hydrogel collapsed.

\section{Materials and Methods}

\subsection{Materials}

Anhydrous ethanol, imidazole, L-phenylalanine, perylene-3,4,9,10-tetracarboxylic dianhydride were purchased from J \& K Scientific Ltd. (Beijing, China). All chemical reagents were used without any further processing. The $N, N^{\prime}$-diphenylalanine-3,4,9,10-tetracarboxylic diimide (NPPD) was synthesized and characterized in the laboratory.

\subsection{Synthesis of NPPD}

An amount of $0.392 \mathrm{~g}(1.0 \mathrm{mmol})$ perylene-3,4,9,10-tetracarboxylic dianhydride, $0.330 \mathrm{~g}(2.0 \mathrm{mmol})$ L-phenylalanine and $2.0 \mathrm{~g}$ imidazole were heated at $90{ }^{\circ} \mathrm{C}$ for $40 \mathrm{~min}$ under nitrogen atmosphere. When the imidazole was melted, the temperature was raised to $120{ }^{\circ} \mathrm{C}$ for $6 \mathrm{~h}$. Then, $25 \mathrm{~mL}$ of $\mathrm{CH}_{3} \mathrm{CH}_{2} \mathrm{OH}$ was poured into the round-bottom flask, refluxed for $6 \mathrm{~h}$ at $90{ }^{\circ} \mathrm{C}$, cooled down at room temperature, then filtered by vacuum suction and washed with $\mathrm{CH}_{3} \mathrm{CH}_{2} \mathrm{OH}$. The sediment was dissolved by $\mathrm{H}_{2} \mathrm{O}$. Then, $1.0 \mathrm{moL} / \mathrm{L} \mathrm{HCl}$ was dropped into the solution until the mixture solution was acidic. The solution was filtered by vacuum suction and washed with $\mathrm{H}_{2} \mathrm{O}$ in ambient temperatures. The product was dried at room temperature to obtain a violet powder (yield: $0.57 \mathrm{~g}, 87 \%$ ). The structure and purity of the product were confirmed by IR (KBr): $1252.4,1396.4,1501.2 \mathrm{~cm}^{-1}(\mathrm{C}=\mathrm{C}), 1344.9,1432.5 \mathrm{~cm}^{-1}$ (-CH2-), 1656.6, 1697.0, $1737.9 \mathrm{~cm}^{-1}$ (C=O), $2934.8 \mathrm{~cm}^{-1}(\mathrm{C}-\mathrm{H}), 3439.3 \mathrm{~cm}^{-1}(\mathrm{O}-\mathrm{H}){ }^{1} \mathrm{H}$ NMR (DMSO, $400 \mathrm{MHz}, \mathrm{ppm}): 8.31-8.45$ (q, 8H), 7.13-7.23 (m, 8H), 7.04-7.08 (t, 2H), 5.92-5.95 (q, 2H), 3.59-3.64 (q, $2 \mathrm{H}), 3.40-3.44(\mathrm{t}, 2 \mathrm{H}), 3.32(\mathrm{~s}, 2 \mathrm{H})$; MALDI-TOF-MS: calcd for $\mathrm{C}_{42} \mathrm{H}_{28} \mathrm{~N}_{2} \mathrm{O}_{8}, 686.1$.

\subsection{Characterization}

Ultraviolet (UV) absorption spectra were obtained using a UV-2700 UV-Vis spectrophotometer and NMR spectra were measured on a Bruker ULTRASHIELD 400 (1H NMR 400 MHz) spectrometer. The Fourier transform-infrared spectroscopy (FT-IR) were recorded on an AVATAR 360 FT-IR spectrophotometer, the powder samples were mixed with $\mathrm{KBr}$ to prepare the thin films in the solid-state FT-IR studies. The luminescence spectra were measured on a LS55 fluorescence spectrophotometer, in which the path length of the quartz cell is $1 \mathrm{~cm}$. The emission bandwidth was $5 \mathrm{~nm}$. SEM images of these samples were recorded using FEI QUANTA 450 with an accelerating voltage of $25.0 \mathrm{kV}$. The samples were obtained by dropping the gels on a cylindrical aluminum substrate and drying at room temperature. Confocal laser scanning microscope (CLSM) images were taken with a confocal laser scanning fluorescent microscope FV 1000 invert microscope (OLYMPUS) under 100× magnifications at an excitation wavelength of $405 \mathrm{~nm}$; the samples were coated with gold using a MSP-1S magnetron sputter (Japan) coater. 


\subsection{Gelation Preparation}

The NPPD $/ \alpha-C D / R F=1: 1: 2$ was put into a capped glass bottle $(5 \mathrm{~mL})$ with $2.0 \mathrm{~mL} \mathrm{~V} \mathrm{~V}_{\mathrm{THF}}: \mathrm{V}_{\mathrm{H} 2 \mathrm{O}}=4: 6$ mixture solvent. Then, the hydrogel was obtained after ultrasonic treatment for $40 \mathrm{~min}$ at $15-20{ }^{\circ} \mathrm{C}$. The critical gelation concentration (CGC) was $0.6 \% w / v$.

\section{5. $\alpha$-Amylase Responsive Test}

An amount of $200 \mu \mathrm{L} \alpha$-amylase (50 U/mL) was added into the hydrogel, and heated 5-10 min at $37^{\circ} \mathrm{C}$. The $\alpha$-CD was gradually hydrolyzed by the $\alpha$-amylase, and the gel eventually collapses.

\section{Results and Discussion}

The chemical structure of NPPD, RF, and $\alpha-C D$ are shown in Figure 1, respectively. The NPPD has been synthesized and characterized as is shown in Supplementary Materials Figure S1. The NPPD has a perylene core and two L-phenylalanine residues. A number of $\pi$ electrons or hydrogen bonding sites are contributing to form hydrogel. The $\alpha$-cyclodextrin $(\alpha-C D)$ has hydroxyls as is shown in Figure $1 b$, which could form hydrogen bonding with the NPPD or RF. Moreover, this is a specific response to $\alpha$-amylase. When the molar ratio of NPPD/RF/ $\alpha-\mathrm{CD}$ is $1 / 1 / 2$, the three-component hydrogel is formed under ultrasound at room temperature (Figure S2).

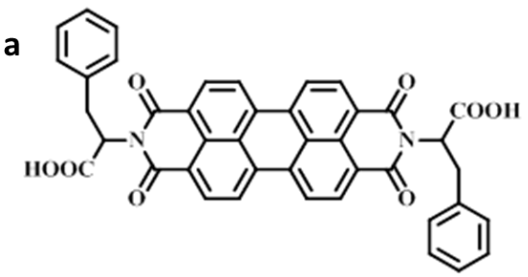

NPPD

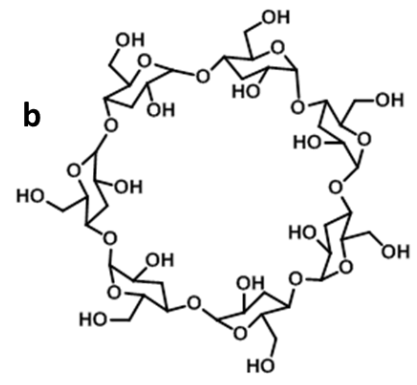

$\alpha-C D$<smiles>Cc1cc2nc3c(=O)[nH]c(=O)cc-3n(CC(O)C(O)C(O)CO)c2cc1C</smiles>

RF

Figure 1. Chemical structures of $N, N^{\prime}$-diphenylalanine-3,4,9,10-tetracarboxylic diimide (NPPD); $\alpha$-cyclodextrin $(\alpha-C D)$; riboflavin $(R F)$.

In order to explore the molecular interactions of the gel, the fluorescence spectrum, ultraviolet spectrum and infrared spectrum were recorded. The fluorescence spectrum of NPPD/ $\alpha-\mathrm{CD} /$ $\mathrm{RF}=1: 1: 2$ in hybrid solution $\left(\mathrm{V}_{\mathrm{THF}} / \mathrm{V}_{\mathrm{H} 2 \mathrm{O}}=4 / 6,[\mathrm{NPPD}]=1.0 \times 10^{-6} \mathrm{~mol} / \mathrm{L}\right)$ was shown in Figure $2 \mathrm{a}$. The absorption peak of the gel and NPPD were observed at $538 \mathrm{~nm}$ in the fluorescence spectrum. However, the fluorescence intensity of NPPD molecules ([NPPD] $=1.0 \times 10^{-6} \mathrm{~mol} / \mathrm{L}$, the black line) was greater than the three-component gel $\left([\mathrm{NPPD}]=1.0 \times 10^{-6} \mathrm{~mol} / \mathrm{L}\right.$, the blue line) in the mixture solution $\left(\mathrm{V}_{\mathrm{THF}} / \mathrm{V}_{\mathrm{H} 2 \mathrm{O}}=4 / 6\right)$. According to the previous study, the fluorescence intensity of perylene-diimide derivatives was enhanced at low concentrations, while the fluorescence intensity tended to be weakened or quenching under the aggregation or solid state [41-44]. This means that the assembly aggregation of the three components has changed. The $\pi-\pi$ stacking of the aggregation is stronger than that of NPPDs. The stronger $\pi-\pi$ stacking effect will make partial quenching fluorescence more intense. When the excitation wavelength is $490 \mathrm{~nm}$, the fluorescence intensity of NPPD/RF is lower than NPPD/CD and NPPD (Figure 2b). We conjecture that the $\pi-\pi$ stacking effect between RF and NPPD is stronger than that of NPPD. NPPDs and RF self-assemble by the hydrogen bond and $\pi-\pi$ stacking interaction in mixed solution with the assistance of ultrasound. Then, four hydroxyls of $\mathrm{RF}$ interacted with the peripheral hydroxyl of CDs via hydrogen bonding. The smaller RF is easier; it enters into the aggregation of NPPD to generate stronger $\pi-\pi$ stacking. 
The UV-Vis spectra of the hydrogel dilute solution were explored, as shown in Figure 2c. The ultraviolet absorption peak maxima of the NPPDs' solution ([NPPD] $=1.0 \times 10^{-5} \mathrm{~mol} / \mathrm{L}$ ) was observed at $371 \mathrm{~nm}, 460 \mathrm{~nm}, 490$, and $526 \mathrm{~nm}$, respectively. Furthermore, the absorption peaks of RF $\left([R F]=2.0 \times 10^{-5} \mathrm{~mol} / \mathrm{L}\right)$ existed at $350 \mathrm{~nm}$. However, in the absorption peak maximum of the gel, a slight change appeared; the absorption peak at $350 \mathrm{~nm}$ and $460 \mathrm{~nm}$ were shifted respectively. The peak at $350 \mathrm{~nm}$ of the gel manifested a somewhat red-shift. It was ascribed to the geometry of the aromatic systems stacking between NPPD and RF and the aggregation of the NPPD/ $\alpha-C D / R F$ system.
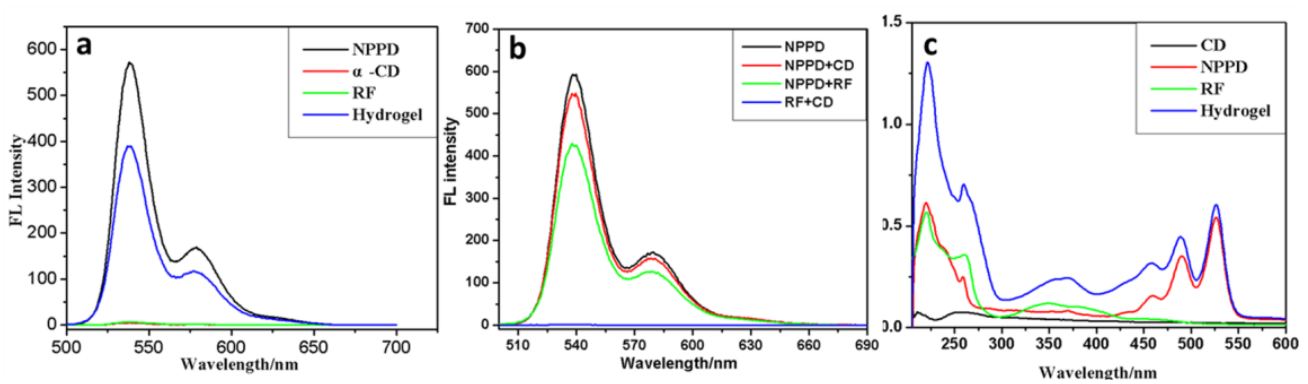

Figure 2. (a) The fluorescence spectra of the hydrogel and one-component solution at room temperature $\left([\mathrm{NPPD}]=10^{-6} \mathrm{~mol} / \mathrm{L},[\alpha-\mathrm{CD}]=10^{-6} \mathrm{~mol} / \mathrm{L},[\mathrm{RF}]=2 \times 10^{-6} \mathrm{~mol} / \mathrm{L}\right) ;(\mathbf{b})$ The fluorescence spectra of the NPPD and two-component solution at room temperature ([NPPD] $=10^{-6} \mathrm{~mol} / \mathrm{L}$, $\left.[\alpha-\mathrm{CD}]=10^{-6} \mathrm{~mol} / \mathrm{L},[\mathrm{RF}]=2 \times 10^{-6} \mathrm{~mol} / \mathrm{L}\right) ;(\mathrm{c}) \mathrm{UV}-\mathrm{Vis}$ spectra of NPPD $/ \alpha-\mathrm{CD} / \mathrm{RF}=1: 1: 2$ system at room temperature $\left([\mathrm{NPPD}]=[\alpha-\mathrm{CD}]=10^{-5} \mathrm{M}\right.$ and $[\mathrm{RF}]=2.0 \times 10^{-5} \mathrm{M}$, [path length $\left.=2.0 \mathrm{~mm}\right]$.

The infrared spectrum was recorded to discuss the driving force of gel factors, especially for the presence of a hydrogen bonding system by the components. In the figure, the strong $\mathrm{C}=\mathrm{O}$ bond of tertiary amides at $1697 \mathrm{~cm}^{-1}$ and $1657 \mathrm{~cm}^{-1}$ in pure NPPD was observed. However, the shift of $\mathrm{C}=\mathrm{O}$ stretching to lower frequency (Figure S5) attests the participation of the H-bond in the gel state. The topography of the gel was observed by scanning electron microscopy (SEM). As is shown in Figure 3, the dried hydrogel formed rod-like structures. The three-component xerogel was composed of a close-knit structure, in which rod-like structures with a diameter ranging from 0.3 to $0.8 \mu \mathrm{m}$ cross-linked with each other to form three-dimensional networks (Figure 3a,b). Additionally, the rod-like bundles crosslinking each other make the pores small enough and stop solvent from flowing which makes the hydrogel stable. In addition, we have done the confocal laser scanning microscope (CLSM) experiment, and found that the gel is fluorescigenic. (Figure S6a,b). The fluorescence morphology of these structures upon excitation at $405 \mathrm{~nm}$ was consistent with the SEM images, which demonstrated that the hydrogel was a luminescent gel with fluorescence.

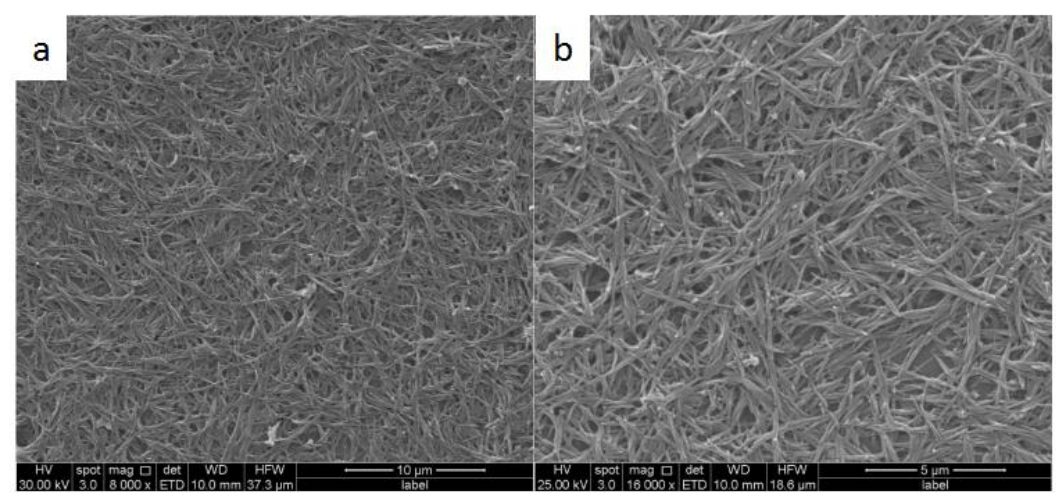

Figure 3. The SEM images of the hydrogel ([NPPD] $=10^{-3} \mathrm{~mol} / \mathrm{L},[\alpha-\mathrm{CD}]=10^{-3} \mathrm{~mol} / \mathrm{L}$, $\left.[R F]=2 \times 10^{-3} \mathrm{~mol} / \mathrm{L}\right)(\mathbf{a})$ the xerogels in a mixed solution for a larger scale; $(\mathbf{b}) \mathrm{NPPD} / \mathrm{RF} / \alpha-\mathrm{CD}$ hydrogel in a mixed solution for a small scale. 
To explore the enzyme-responsive function of the hydrogel, a series of characterizations were performed. The fluorescence spectrum of the hydrogel after $\alpha$-amylase processing was recorded (Figure 4a). Compared with the fluorescence gel, the fluorescence intensity of the gel after enzyme treatment decreased a lot. The fluorescence intensity of the hydrogel after $\alpha$-amylase processing is almost the same as the pure two-component solution (the black line). In addition, the pure gel performance of $\alpha$-amylase-responsive gel was recorded. When the $\alpha$-amylase was added into the hydrogel after $10 \mathrm{~min}$ at $37^{\circ} \mathrm{C}$, the hydrogel collapsed. The result is shown in the optical images of Figure $4 \mathrm{~b}$. This result is due to the $\alpha-\mathrm{CD}$ in the gel hydrolyzed by $\alpha$-amylase. This means that the hydrogel has the enzyme-responsive function of $\alpha$-amylase.
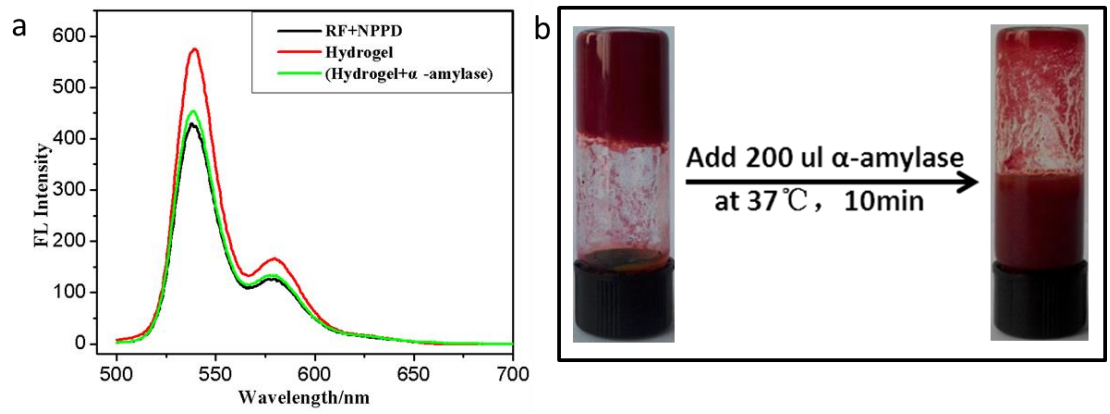

Figure 4. (a) The fluorescence spectrum of the hydrogel and two-component solution at room temperature $\left([\mathrm{NPPD}]=1.0 \times 10^{-6} \mathrm{~mol} / \mathrm{L},[\mathrm{RF}]=2 \times 10^{-6} \mathrm{~mol} / \mathrm{L},[\alpha-\mathrm{CD}]=1.0 \times 10^{-6} \mathrm{~mol} / \mathrm{L}\right.$, $[\alpha$-amylase $]=0.001 \mathrm{~mol} / \mathrm{L})$. (b) The optical images show the gel hydrolyzed by $\alpha$-amylase.

As further evidence of the enzyme responsiveness of the gel, the surface morphology after the gel was hydrolyzed was observed by a scanning electron microscope, as shown in Figure 5. In the figure, the close-knit structure was observed, in which fine-spun fibers with a diameter ranging from 0.1 to $0.7 \mathrm{um}$ intertwined with each other to form three-dimensional networks after the xerogel was hydrolyzed by $\alpha$-amylase (Figure 5a,b). The fluorescence of the hydrogel after $\alpha$-amylase processing could be observed under a confocal laser scanning microscope (CLSM) upon excitation at $405 \mathrm{~nm}$. It was observed that the compact network structures were composed of long and interlaced fibers without fluorescence (Figure S6c,d). When the $\alpha$-CD was hydrolyzed, the $\pi-\pi$ stacking between NPPD and RF/NPPD is stronger. Then, the fluorescence was quenching. The morphology of these structures upon excitation at $405 \mathrm{~nm}$ was consistent with the SEM images.
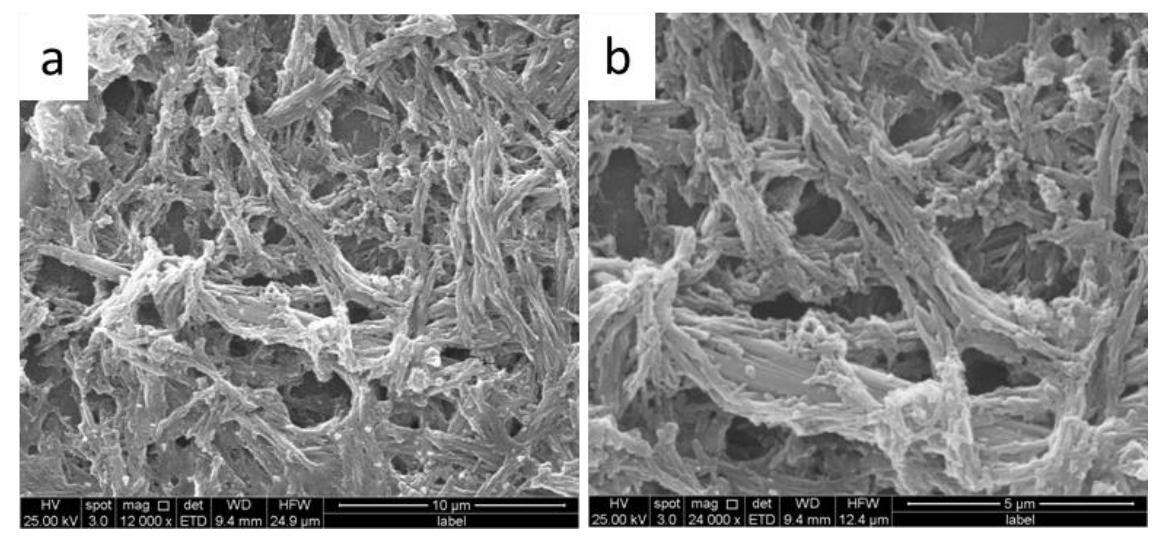

Figure 5. The SEM images of the gel after $\alpha$-amylase processing ([NPPD] $=10^{-3} \mathrm{~mol} / \mathrm{L}$, $[\alpha-\mathrm{CD}]=10^{-3} \mathrm{~mol} / \mathrm{L},[\mathrm{RF}]=2 \times 10^{-3} \mathrm{~mol} / \mathrm{L},[\alpha$-amylase $\left.]=0.01 \mathrm{U} \cdot \mathrm{mL}^{-1}\right),(\mathbf{a})$ the xerogels after $\alpha$-amylase processing in a mixed solution for a larger scale; (b) For hydrogel in a mixed solution in a small scale. 


\section{Conclusions}

We have discovered an enzyme-responsive three-component hydrogel, which was composed of amino acids-functionalized perylene derivatives, riboflavin and $\alpha$-CD. The hydrogels exhibited a specific $\alpha$-amylase response and fluorescence properties. Such properties open the possibility for hydrogels to become potential materials in the field of drug delivery and stimulation-response.

Supplementary Materials: The following are available online at www.mdpi.com/2227-9040/5/1/6/s1.

Acknowledgments: The research was supported by National Natural Science Foundation of China (No. 21365003, 21463003, 51478123). The Jiangxi outstanding youth fund (20153BCB23001) and Jiangxi Provincal project of scientific and technological innovation team (20152BCB24008) are also gratefully acknowledged.

Author Contributions: Y.L. conceived and designed the experiments; W.L. and Y.F. performed the experiments; Y.P. and Y.W. analyzed the data; X.L. and X.F. contributed reagents/materials/analysis tools; Y.P. wrote the paper.

Conflicts of Interest: The authors declare no conflict of interest.

\section{References}

1. Lim, H.L.; Wang, Y.H.; Kar, M.; Varghese, S. Smart hydrogels as functional biomimetic systems. Biomater. Sci. 2014, 2, 603-618. [CrossRef]

2. Li, Y.; Liu, W.; Cheng, L.X.; Huang, P.; Peng, Y.; Wu, Y.; Li, X.; Li, X.K.; Fan, X.L. A Smart pH-Responsive Three Components Luminescent Hydrogel. J. Funct. Biomater. 2016, 7, 25. [CrossRef] [PubMed]

3. Yoshida, R.; Okano, T. (Eds.) Stimuli-Responsive Hydrogels and Their Application to Functional Materials; Springer: New York, NY, USA, 2010.

4. Henderson, P.W.; Singh, S.P.; Krijgh, D.D.; Yamamoto, M.; Rafii, D.C.; Sung, J.J.; Rafii, S.; Rabbany, S.Y.; Spector, J.A. Stromal-derived factor-1 delivered via hydrogel drug-delivery vehicle accelerates wound healing in vivo. Wound Repair Regener. 2011, 19, 420-425. [CrossRef] [PubMed]

5. Hoare, T.R.; Kohane, D.S. Hydrogels in drug delivery: Progress and challenges. Polymer 2008, 49, $1993-2007$. [CrossRef]

6. Drury, J.L.; Mooney, D.J. Hydrogels for tissue engineering: Scaffold design variables and applications. Biomaterials 2003, 24, 4337-4351. [CrossRef]

7. Hu, J.; Zhang, G.; Liu, S. Enzyme-responsive polymeric assemblies, nanoparticles and hydrogels. Chem. Soc. Rev. 2012, 41, 5933-5949. [CrossRef] [PubMed]

8. Ulijn, R.V. Enzyme-responsive materials: A new class of smart biomaterials. J. Mater. Chem. 2006, 16, 2217-2225. [CrossRef]

9. Zelzer, M.; Todd, S.J.; Hirst, A.R.; McDonald, T.O.; Ulijn, R.V. Enzyme responsive materials: Design strategies and future developments. Biomater. Sci. 2013, 1, 11-39. [CrossRef]

10. Kessenbrock, K.; Plaks, V.; Werb, Z. Matrix metalloproteinases: Regulators of the tumor microenvironment. Cell 2010, 141, 52-67. [CrossRef] [PubMed]

11. Liotta, L.A.; Tryggvason, K.; Garbisa, S.; Hart, I.; Foltz, C.M.; Shafie, S. Metastatic potential correlates with enzymatic degradation of basement membrane collagen. Nature 1980, 284, 67-68. [CrossRef] [PubMed]

12. Kumar, V.A.; Shi, S.; Wang, B.K.; Li, I.; Jalan, A.A.; Sarkar, B.; Wickremasinghe, N.C.; Hartgerink, J.D. Drug-triggered and cross-linked self-assembling nanofibrous hydrogels. J. Am. Chem. Soc. 2015, 137, 4823-4830. [CrossRef] [PubMed]

13. Habibia, N.; Kamalyb, N.; Memicc, A.; Shafieea, H. Self-assembled peptide-based nanostructures: Smart nanomaterials toward targeted drug delivery. Nano Today 2016, 11, 41-60. [CrossRef] [PubMed]

14. Choe, S.; Bond, C.W.; Harrington, D.A.; Stupp, S.I.; McVary, K.T.; Podlasek, C.A. Peptide amphiphile nanofiber hydrogel delivery of sonic hedgehog protein to the cavernous nerve to promote regeneration and prevent erectile dysfunction. Nanotechnol. Biol. Med. 2017, 13, 95-101. [CrossRef] [PubMed]

15. Jiang, L.; Yan, Y.; Drechsler, M.; Huang, J. Enzyme-triggered model self-assembly in surfactant-cyclodextrin systems. Chem. Commun. 2012, 48, 7347-7349. [CrossRef] [PubMed]

16. Zhang, X.; Wang, C. Supramolecular amphiphiles. Chem. Soc. Rev. 2011, 40, 94-101. [CrossRef] [PubMed]

17. Wang, C.; Wang, Z.; Zhang, X. Amphiphilic building blocks for self-assembly: From amphiphiles to supra-amphiphiles. Acc. Chem. Res. 2012, 45, 608-618. [CrossRef] [PubMed] 
18. Wang, C.; Wang, Z.; Zhang, X. Superamphiphiles as building blocks for supramolecular engineering: Towards functional materials and surfaces. Small 2011, 7, 1379-1383. [CrossRef] [PubMed]

19. Wang, G.; Wang, C.; Wang, Z.; Zhang, X. Bolaform superamphiphile based on a dynamic covalent bond and its self-assembly in water. Langmuir 2011, 27, 12375-12380. [CrossRef] [PubMed]

20. Liu, K.; Yao, Y.; Liu, Y.; Wang, C.; Li, Z.; Zhang, X. Self-assembly of supra-amphiphiles based on dual charge-transfer interactions: From nanosheets to nanofibers. Langmuir 2012, 28, 10697-10702. [CrossRef] [PubMed]

21. Han, P.; Ma, N.; Ren, H.; Xu, H.; Li, Z.; Wang, Z.; Zhang, X. Oxidation-responsive micelles based on a selenium-containing polymeric superamphiphile. Langmuir 2010, 26, 14414-14418. [CrossRef] [PubMed]

22. Wang, C.; Guo, Y.; Wang, Z.; Zhang, X. Superamphiphiles based on charge transfer complex: Controllable hierarchical self-assembly of nanoribbons. Langmuir 2010, 26, 14509-14511. [CrossRef] [PubMed]

23. Liu, Y.; Liu, K.; Wang, Z.; Zhang, X. Host-Enhanced $\pi-\pi$ Interaction for Water-Soluble Supramolecular Polymerization. Chem. Eur. J. 2011, 17, 9930-9935. [CrossRef] [PubMed]

24. Marchesan, S.; Vargiu, A.V.; Styan, K.E. The Phe-Phe motif for peptide self-assembly in nanomedicine. Molecules 2015, 20, 19775-19788. [CrossRef] [PubMed]

25. Han, P.; Li, S.; Wang, C.; Xu, H.; Wang, Z.; Zhang, X. UV-responsive polymeric superamphiphile based on a complex of malachite green derivative and a double hydrophilic block copolymer. Langmuir 2011, 27, 14108-14111. [CrossRef] [PubMed]

26. Roy, D.; Cambre, J.N.; Sumerlin, B.S. Future perspectives and recent advances in stimuli-responsive materials. Polym. Sci. 2010, 35, 278-301. [CrossRef]

27. Williams, R.J.; Mart, R.J.; Ulijn, R.V. Exploiting biocatalysis in peptide self-assembly. Biopolymers 2010, 94, 107-117. [CrossRef] [PubMed]

28. Hahn, M.E.; Gianneschi, N.C. Enzyme-directed assembly and manipulation of organic nanomaterials. Chem. Commun. 2011, 47, 11814-11821. [CrossRef] [PubMed]

29. Yang, Z.; Liang, G.; Xu, B. Enzymatic hydrogelation of small molecules. Acc. Chem. Res. 2008, 41, 315-326. [CrossRef] [PubMed]

30. Börner, H.G.; Kühnle, H.; Hentschel, J. Making "smart polymers" smarter: Modern concepts to regulate functions in polymer science. J. Polym. Sci. Part A Polym. Chem. 2010, 48, 1-14. [CrossRef]

31. Kang, Y.; Wang, C.; Liu, K.; Wang, Z.; Zhang, X. Enzyme-responsive polymeric supra-amphiphiles formed by the complexation of chitosan and ATP. Langmuir 2012, 28, 14562-14566. [CrossRef]

32. Xing, Y.; Wang, C.; Han, P.; Wang, Z.; Zhang, X. Acetylcholinesterase responsive polymeric supra-amphiphiles for controlled self-assembly and disassembly. Langmuir 2012, 28, 6032-6036. [CrossRef] [PubMed]

33. Peltier, R.; Chen, G.; Lei, H.; Zhang, M.; Gao, L.; Lee, S.S.; Wang, Z.; Sun, H. The rational design of a peptide-based hydrogel responsive to $\mathrm{H}_{2} \mathrm{~S}$. Chem. Commun. 2015, 51, 17273-17276. [CrossRef] [PubMed]

34. Inouye, H.; Sharma, D.; Goux, W.J.; Kirschner, D.A. Structure of core domain of fibril-forming PHF/Tau fragments. Biophys. J. 2006, 90, 1774-1789. [CrossRef] [PubMed]

35. Gazit, E. A possible role for $\pi$-stacking in the self-assembly of amyloid fibrils. FASEB J. 2002, 16, 77-83. [CrossRef] [PubMed]

36. Makin, O.S.; Serpell, L.C. Structures for amyloid fibrils. FEBS J. 2005, 272, 5950-5961. [CrossRef] [PubMed]

37. Gazit, E. Global analysis of tandem aromatic octapeptide repeats: The significance of the aromatic-glycine motif. Bioinformatics. 2002, 18, 880-883. [CrossRef] [PubMed]

38. Adler-Abramovich, L.; Vaks, L.; Carny, O.; Trudler, D.; Magno, A.; Caflisch, A.; Frenkel, D.; Gazit, E. Phenylalanine assembly into toxic fibrils suggests amyloid etiology in phenylketonuria. Nat. Chem. Biol. 2012, 8, 701-706. [CrossRef] [PubMed]

39. Krieg, E.; Shirman, E.; Weissman, H.; Shimoni, E.; Wolf, S.G.; Pinkas, I.; Rybtchinski, B. Supramolecular gel based on a perylene diimide dye: Multiple stimuli responsiveness, robustness, and photofunction. J. Am. Chem. Soc. 2009, 131, 14365-14373. [CrossRef] [PubMed]

40. Bairi, P.; Roy, B.; Nandi, A.K. A light harvesting Bi-component hydrogel with a riboflavin acceptor. Chem. Commun. 2012, 48, 10850-10852. [CrossRef] [PubMed]

41. Wang, C.; Kang, Y.; Liu, K.; Li, Z.; Wang, Z.; Zhang, X. pH and enzymatic double-stimuli responsive multi-compartment micelles from supra-amphiphilic polymers. Polym. Chem. 2012, 3, 3056-3059. [CrossRef] 
42. Wurthner, F.; Kaiser, T.E.; Saha-Moller, C.R. J-Aggregates: From Serendipitous Discovery to Supramolecular Engineering of Functional Dye Materials. Angew. Chem. Int. Ed. 2011, 50, 3376-3410. [CrossRef] [PubMed]

43. Bullock, J.E.; Carmieli, R.; Mickley, S.M.; Vura-Weis, J.; Wasielewski, M.R. Photoinitiated charge transport through $\pi$-stacked electron conduits in supramolecular ordered assemblies of donor-acceptor triads. J. Am. Chem. Soc. 2009, 131, 11919-11929. [CrossRef] [PubMed]

44. Malinovskii, L.V.; Wenger, D.; Haener, R. Nucleic acid-guided assembly of aromatic chromophores. Chem. Soc. Rev. 2010, 39, 410-422. [CrossRef] [PubMed]

(c) 2017 by the authors; licensee MDPI, Basel, Switzerland. This article is an open access article distributed under the terms and conditions of the Creative Commons Attribution (CC BY) license (http:/ / creativecommons.org/licenses/by/4.0/). 